\title{
PENGARUH GAME ONLINE PUBG TERHADAP INDEKS PRESTASI MAHASISWA PTI FKIP UNISRI
}

\author{
Arif Sutikno $^{1}$ dan Yudhistiro Pandu Widhoyoko ${ }^{2}$ \\ ${ }^{1}$ Program Studi Pendidikan Teknologi Informasi \\ Universitas Slamet Riyadi Surakarta, 57126, Indonesia \\ arif.stk@gmail.com \\ ${ }^{2}$ Program Studi Pendidikan Teknologi Informasi \\ Universitas Slamet Riyadi Surakarta, 57126, Indonesia \\ yudhistirowidhoyoko@gmail.com
}

\begin{abstract}
ABSTRAK
Perkembangan game baik pada alatnya, teknologinya, bahkan kesenangannya semakin meningkat dengan pesat. Seтиа remaja, termasuk mahasiswa, menyambut gembira hal ini. teknologi semakin modern dan cepat. Setiap remaja tidak dibatasi untuk bisa mengakses informasi yang ada, karena semua tersedia di internet dengan mudah, cepat dan murah. Namun dibalik kemudahan akses mendapatkan kesenangan tersebut, tersembunyi bahaya yang pantas untuk diwaspadai.. Rasa menyenangkan dalam bermain game ini dapat mematikan rangsangan alami manusia seperti maksn, minum, tidur, dan buang air. Jika rangsangan tersebut diabaikan, bagaimana denganbelajar dan hasil belajar bagi mahasiswa yang bermain game aktif. terutama yang ada di internet.

Secara umum penelitian ini bertujuan untuk menggambarkan secara umum kepada masyarakat mengenai potensi bahaya yang terkandung dalam bermain game online. Bermain game sangatlah menyenangkan akan tetapi dengan level adiksi yang sama dengan narkoba.

Metode yang digunakan dalam penelitian ini adalah metode deskriptif. Penelitian deskriptif ini bertujuan untuk membuat gambaran deskriptif secara akurat, factual, dan sistematis tentang sifat dan fakta beserta hubungan antar fenomena yang diteliti dengan teknik pengumpulan data observasi, angket, dan studi dokumen. Jumlah responden lima puluh orang Mahasiswa pemain aktif game online PUBG di Prodi Teknologi Informasi FKIP Unisri tahiun ajaran 2018/2019.

Kesimpulan dari penelitian ini adalah bahwa jumlah mahasiswa yang indeks nilainya terpengaruh karena bermain game online ini sebesar $82 \%$. Sedangkan, mahasiswa yang indeks nilainya tidak terpengaruh karena bermain game online ini sebesar $17 \%$.
\end{abstract}

Keywords: Game Online, PUBG, Indeks Prestasi Kumulatif 


\section{Pendahuluan}

Seorang mahasiswa strata 1 mempunyai kewajiban untuk belajar dan mengerjakan tugas-tugas di dalam kampus yang diberikan oleh Dosennnya. Rata-rata, mereka harus menyelesaikan sebanyak 140an sks yang umumnya ditempuh selama kurun waktu empat tahun terbagi dalam delapan semester. Dimana di tiap semester, mahasiswa mendapatkan rata-rata 20an sks yang harus ditempuh dan diselesaikan.

Selama rentang waktu kurang lebih empat tahun tersebut, kadang-kadang timbul rasa bosan dalam belajar dan mengerjakan tugas dalam kampus. Dan harus diimbangi dengan kegiatan-kegiatan lain yang sifatnya menghibur atau entertaining.

Kegiatan entertaining tersebut masuk ke ranah hobby. Bisa bermacam-macam bentuk dan jenisnya. Ada yang bersifat keolahragaan, seni, melakukan kegiatan pemeliharaan baik tumbuh-tumbuhan maupun hewan, maupun, yang sekarang ini sedang trend adalah, bermain game online menggunakan media smartphone, laptop, maupun PC. Adalah PUBG, game online yang ternyata sangat marak dimainkan oleh para remaja bahkan dewasa sehingga melupakan waktu. Pun sama halnya dengan yang dialami oleh para mahasiswa Prodi PTI FKIP Unisri Surakarta dari semua angkatan. Mulai dari semester satu hingga tujuh, terutama para lelaki, sangatlah menggemari permainan ini.
Akan tetapi, masalah baru muncul. Salah satu dari beberapa pilihan kegiatan sebagai obat kepenatan atas beban rutinitas tersebut, ternyata cukup menyita waktu. Sehingga mengambil jatah waktu yang seharusnya dipakai sebagai porsi melakukan kegiatan kampus yaitu belajar dan megerjakan tugastugas dari dosen. Dan yang sering muncul sebagai penyita waktu terbanyak adalah bermain game online.

Dugaan-dugaan yang muncul terkait dengan kecenderungan para mahasiswa Prodi PTI FKIP Unisri Surakarta terhadap kegiatan belajar mengajar di dalam kampus ini akan dicari tahu dalam penelitian ini. Peneliti akan mencari tahu berapa lama waktu belajar dan mengerjakan tugas kuliah mereka sebelum dan sesudah para mahasiswa tersebut mengenal Game PUBG ini. Dan juga peneliti juga akan meneliti apakah mereka sudah dalam taraf kecanduan dalam bermain game ini. Yang ketiga dan terakhir, apakah kegiatan bermain game ini sangatlah menyita tenaga, waktu, dan pikiran mereka sehingga menjadikan nilai indeks prestasi kumulatif mereka turun.

Berdasarkan latar belakang yang telah diuraikan, sehingga rumusan penelitian adalah sebagai berikut: Apakah game PUBG mempengaruhi indeks Prestasi Kumulatif mahasiswa PTI FKIP Unisri? Seberapa pengaruh mahasiswa yang bermain game PUBG terhadap indeks prestasi kumulatifnya? 


\section{Tinjauan Pustaka}

A. Game Online

Game online adalah game yang dimainkan melalui Internet atau jaringan komputer lain yang tersedia. Game online ada di mana-mana pada platform game modern, termasuk PC, konsol, dan perangkat seluler, dan menjangkau banyak genre, termasuk penembak orang pertama, game strategi, dan game bermain peran (MMORPG) multiplayer online besarbesaran. Desain game online dapat berkisar dari lingkungan berbasis teks sederhana hingga penggabungan grafik yang kompleks dan dunia virtual. Keberadaan komponen online dalam game dapat berkisar dari fitur kecil, seperti papan pemimpin online, hingga menjadi bagian dari gameplay inti, seperti bermain langsung melawan pemain lain. Banyak game online membuat komunitas online mereka sendiri, sementara game lain, terutama game sosial, mengintegrasikan komunitas kehidupan nyata para pemain yang ada. Budaya permainan online terkadang menghadapi kritik untuk lingkungan yang mungkin mendorong intimidasi, kekerasan, dan xenofobia dunia maya. Beberapa juga khawatir tentang kecanduan game atau stigma sosial. Game online telah menarik pemain dari berbagai usia, kebangsaan, dan pekerjaan. Konten game online juga dapat dipelajari dalam bidang ilmiah, terutama interaksi gamer dalam masyarakat virtual sehubungan dengan perilaku dan fenomena sosial kehidupan sehari-hari.
Sejarah game online berawal dari jaringan komputer berbasis paket pada tahun 1970-an, Contoh awal game online adalah MUD, termasuk yang pertama, MUD1, yang dibuat pada tahun 1978 dan awalnya terbatas pada jaringan internal sebelum menjadi terhubung ke ARPANet pada tahun 1980. Game komersial diikuti pada dekade berikutnya, dengan Islands of Kesmai, game role-playing komersial online pertama, memulai debutnya pada tahun 1984, serta lebih banyak game grafis, seperti game aksi MSX LINKS pada tahun 1986, simulator penerbangan Air Warrior pada tahun 1987, dan game Go Famicom Modem online pada tahun 1987.

\section{B. PlayerUnknown's Battlegrounds (PUBG)}

Player Unknown's Battlegrounds (PUBG) adalah game royale multiplayer pertempuran online 2017 yang dikembangkan dan diterbitkan oleh PUBG Corporation, anak perusahaan perusahaan video game Korea Selatan Bluehole. Gim ini didasarkan pada modmod sebelumnya yang dibuat oleh Brendan "Player Unknown" Greene untuk gim lain, terinspirasi oleh film 2000 Battle Jepang, dan diperluas menjadi gim mandiri di bawah arahan kreatif Greene. Battlegrounds pertama kali dirilis untuk Microsoft Windows melalui program beta akses awal Steam pada Maret 2017, dengan rilis penuh pada 20 Desember 2017. 
Battlegrounds menerima ulasan positif dari para kritikus, yang menemukan bahwa sementara permainan masih belum sepenuhnya selesai dan memiliki beberapa kelemahan teknis, itu menyajikan jenis permainan baru yang dapat dengan mudah didekati oleh pemain dari tingkat keterampilan apa pun dan sangat harus dibayar kembali. Permainan menerima beberapa nominasi Games of the Year di antara penghargaan lainnya, dan dianggap oleh Greene sebagai game yang menentukan genre pertempuran royale.

\section{Index Prestasi Kumulatif Mahasiswa}

Indeks prestasi, biasa disingkat IP, adalah salah satu alat ukur prestasi di bidang akademik/pendidikan. Meskipun bernama "indeks", IP sebenarnya bukanlah indeks dalam pengertian sebenarnya, melainkan semacam rerata terboboti.

Penggunaan IP di Indonesia memiliki perbedaan untuk tingkat dasarmenengah dan tingkat pendidikan tinggi. Sistem ini menggantikan sistem rata-rata yang dipakai sampai Kurikulum 1875. Semenjak Kurikulum 1984 berlaku, IP dipakai untuk mengevaluasi pencapaian siswa atau mahasiswa.

Pada tingkat pendidikan tinggi, IP dihitung sebagai rerata norma nilai yang diperoleh seorang mahasiswa pada mata kuliah tersebut setelah diberi bobot dengan "Angka Kredit". Norma nilai berkisar antara 4 (A, terbaik) sampai 0 (E, gagal). Angka Kredit ditentukan besarnya (biasanya 1 sampai 4 Satuan Kredit Semester/SKS) berdasarkan bobot setiap mata kuliah. Bobot ini ditentukan berdasarkan pentingnya mata kuliah tersebut dalam membentuk kompetensi lulusan. IP dihitung untuk setiap semester.

Indeks Prestasi Kumulatif adalah penghitungan IP dengan menggabungkan semua mata kuliah yang telah ditempuh sampai suatu semester tertentu. Indeks Prestasi Semester adalah penghitungan IP dengan semua mata kuliah yang telah ditempuh untuk tiap semester tertentu.

\section{Metode Penelitian}

A. Pendekatan Penelitian Penelitian ini bertujuan untuk mengetahui hubungan dari pengaruh game online PUBG yang dimainkan oleh para mahasiswa PTI FKIP Unisri Surakarta terhadap indeks nilai kumulatif mahasiswa tersebut. Berdasarkan tujuan tersebut, Metode yang digunakan dalam penelitian ini adalah metode deskiptif. Metode deskriptif berfungsi untuk menjelaskan secara deskriptif suatu peristiwa dan suatu gejala yang sedang trend pada situasi sekarang menggunakan prosedur pemecahan masalah dengan menggambarkan keadaan suatu 
Research Fair Unisri 2019

Vol 4, Number 1, Januari 2020

subjek atau objek dalam penelitian. Subjek atau objek itu dapat berupa fakta-fakta yang tampak apa adanya pada orang-orang, lembaga, institusi, masyarakat dan fakta lainnya yang terjadi pada saat sekarang.

Menurut Nazir (1988:63) dalam Buku Contoh Metode Penelitian, metode deskritif merupakan suatu metode dalam meneliti status sekelompok manusia, suatu objek, suatu set kondisi, suatu sistem pemikiran ataupun suatu kelas peristiwa pada masa sekarang. Penelitian deskriptif ini bertujuan untuk membuat gambaran deskriptif secara akurat, factual, dan sistematis tentang sifat dan fakta beserta hubungan antar fenomena yang diteliti.

Maka dari itu, penelitian bermaksud untuk mencari tahu hubungan antara mahasiswa PTI FKIP Unisri Surakarta yang getol bermain game online PUBG 20182019 terhadap nilai akademis atau indeks prestasi mereka. Informasi yang ditemukan peneliti akan dideskripsikan sebagaimana adanya, menurut data yang ditemukan di lapangan.

B. Jenis dan Sumber Data

1. Jenis Data

Data adalah semua fakta baik berupa angka yang dapat dikategorikan untuk menyusun informasi. Data yang akan didapatkan berupa jawaban responden terhadap angket tertulis yang menanyakan sikap mahasiswa PTI FKIP
P- ISSN: 2550-0171

E- ISSN: 2580-5819

UNISRI Surakarta terhadap pilihan jawaban yang berupa pernyataan "ya" atau "tidak".

2. Sumber Data

Sumber data dari penelitian ini adalah semua mahasiswa PTI FKIP UNISRI Surakarta di tahun ajaran 2018/2019 dengan rincian yang terdapat di tabel dibawah ini:

\begin{tabular}{|c|c|c|}
\hline NO & Mahasiswa TA 18/19 & Jumlah \\
\hline 1 & Semester I & 20 \\
\hline 2 & Semester III & 10 \\
\hline 3 & Semester V & 10 \\
\hline 4 & Semester VII & 10 \\
\hline & TOTAL & 50 \\
\hline
\end{tabular}

Populasi dalam penelitian ini adalah semua mahasiswa PTI FKIP Unisri yang bermain aktif game online PUBG tahun ajaran 2018/2019 yang berjumah 50 orang. Dalam penelitian ini, sampel akan diambil secara keseluruhan.

C. Teknik Pengumpulan Data (penelitian)

Pengumpulan data adalah proses pengadaan data untuk keperluan penelitian. Angket digunakan dalam rangka pengumpulan data dengan bentuk berupa daftar pertanyaan dengan hanya dua pilihan jawaban yaitu "ya" atau "tidak".

\section{Pelaksanaan Penelitian}

\section{A. Pengembangan Instrument}

Seperti yang peneliti sampaikan diatas, bahwa peneliti menggunakan teknik angket (kuesioner) dengan cara membuat sejumlah pertanyaan pada angket tersebut. Pertanyaan tersebut terdiri dari sebelas butir 
dimana setiap pertanyaan disertai dengan hanya dua pilihan jawaban yaitu a.ya dan b.tidak.

Pertanyaan-pertanyaan dalam angket tersebut bervariasi macamnya, akan tetapi, inti pertanyaan seputar keadaan IPK mahasiswa berkaitan dengan kegiatan bermain Game online PUBG secara intens yang bahkan cenderung berlebihan. Responden diminta menentukan pilihan jawaban secara jujur, terhadap masalahmasalah yang ditanyakan.

\section{B. Analisis Data}

Data diolah dan dianalisis setelah data diperoleh melalui angket, dengan langkah-langkah seperti berikut,

1. Perhitungan data dengan teknik Tall yng.

Data dihitung satu persatu ketika masih berupa lembar jawaban dari responden. Setiap pilihan jawaban ditandai dengan satu lurus (garis tegak lurus atau ajir) dan kemudian di masukkan kedalam table. Hal ini dilakukan setiap kali menemukan satu jawaban kemudian dibuatkan satu lurus sesuai dengan kelompoknya.

2. Perhitungan frekuensi jawaban setiap pilihan jawaban.

Pada bagian akhir, semua lurus dijumlah dan akan ditemukan frekuensi pada setiap pilihan jawaban, setelah semua jawaban di periksa dan di tandai dengann lurus.
3. Pengolahan data dengan mencari persentase jawaban

Peneliti mendapatkan data mentah hasil angket sampai dengan langkah kedua diatas selesai dilaksanakan. Supaya data mentah dapat diinterpretasikan, maka harus diolah secara lebih lanjut menggunakan rumus guna menemukan persentase masingmasing jawaban yang muncul.

Adapun rumus yang digunakan adalah sebagai berikut:

$\mathrm{X}=$

Keterangan:

$\mathrm{X}$ : Persentase

F: Frekuensi jawaban yang muncul

$\mathrm{N}$ : Jumlah seluruh responden

Dengan menggunakan rumus diatas maka hasil perhitungan data adalah sebagai berikut:

1. Perhitungan data jawaban pertanyaan nomor satu

Pertanyaan:

Banyak dari kalangan pelajar dan mahasiswa yang aktif bermain game. Apakah anda juga pemain game aktif?

\begin{tabular}{|c|c|c|c|}
\hline $\begin{array}{c}\mathrm{N} \\
\mathrm{O}\end{array}$ & $\begin{array}{c}\text { Tanggap } \\
\text { an }\end{array}$ & $\begin{array}{c}\text { frekuen } \\
\text { si }\end{array}$ & $\begin{array}{c}\text { Persenta } \\
\text { se }\end{array}$ \\
\hline 1 & Ya & 50 & $100 \%$ \\
\hline 2 & Tidak & 0 & $0 \%$ \\
\hline & TOTAL & 50 & $100 \%$ \\
\hline
\end{tabular}

2. Perhitungan data jawaban pertanyaan nomor dua

Pertanyaan:

Bahwa game baik online maupun online mengandung kesenangan dan berpotensi kacanduan. Apakah anda mengetahui 
bahwa game online berpotensi membuat pemainnya kecanduan?

\begin{tabular}{|c|c|c|c|}
\hline $\begin{array}{c}\mathrm{N} \\
\mathrm{O}\end{array}$ & $\begin{array}{c}\text { Tanggap } \\
\text { an }\end{array}$ & $\begin{array}{c}\text { frekuen } \\
\text { si }\end{array}$ & $\begin{array}{c}\text { Persenta } \\
\text { se }\end{array}$ \\
\hline 1 & Ya & 15 & $30 \%$ \\
\hline 2 & Tidak & 35 & $70 \%$ \\
\hline & TOTAL & 50 & $100 \%$ \\
\hline
\end{tabular}

3. Perhitungan data jawaban pertanyaan nomor tiga.

Pertanyaan:

Kebutuhan untuk bermain game sudah sangat utama bahkan mengalahkan kewajiban makan dan tidur. Apakah anda juga demikian?

\begin{tabular}{|l|l|l|l|}
\hline $\begin{array}{l}\mathrm{N} \\
\mathrm{O}\end{array}$ & $\begin{array}{l}\text { Tanggap } \\
\text { an }\end{array}$ & $\begin{array}{l}\text { frekuen } \\
\text { si }\end{array}$ & $\begin{array}{l}\text { Persenta } \\
\text { se }\end{array}$ \\
\hline 1 & Ya & 48 & $96 \%$ \\
\hline 2 & Tidak & 2 & $4 \%$ \\
\hline & TOTAL & 50 & $100 \%$ \\
\hline
\end{tabular}

4. Perhitungan data jawaban pertanyaan nomor empat.

Pertanyaan:

Karena sangat terasa nikmatnya bermain game minimal lima jam sehari juga masih terasa kurang. Apakah anda juga demikian?

\begin{tabular}{|l|l|l|l|}
\hline $\begin{array}{l}\mathrm{N} \\
\mathrm{O}\end{array}$ & $\begin{array}{l}\text { Tanggap } \\
\text { an }\end{array}$ & $\begin{array}{l}\text { frekuen } \\
\text { si }\end{array}$ & $\begin{array}{l}\text { Persenta } \\
\text { se }\end{array}$ \\
\hline 1 & Ya & 40 & $80 \%$ \\
\hline 2 & Tidak & 10 & $20 \%$ \\
\hline & TOTAL & 50 & $100 \%$ \\
\hline
\end{tabular}

5. Perhitungan data jawaban pertanyaan nomor lima

Pertanyaan:

Karena sangat mengasyikkan sehingga bermain game sampai dengan lebih dari pukul 01.00 pagi atau lebih. Apakah anda menyadari hal tersebut?

\begin{tabular}{|l|l|l|l|}
\hline $\begin{array}{l}\text { N } \\
\mathrm{O}\end{array}$ & $\begin{array}{l}\text { Tanggap } \\
\text { an }\end{array}$ & $\begin{array}{l}\text { frekuen } \\
\text { si }\end{array}$ & $\begin{array}{l}\text { Persenta } \\
\text { se }\end{array}$ \\
\hline 1 & Ya & 46 & $92 \%$ \\
\hline 2 & Tidak & 4 & $8 \%$ \\
\hline & TOTAL & 50 & $100 \%$ \\
\hline
\end{tabular}

6. Perhitungan data jawaban pertanyaan nomor enam

Pertanyaan:

Banyak pemain aktif game online lupa waktu dalam bermain hingga mengurangi jumlah jam tidur malam mereka. Apakah anda juga merasa terkurangi jumlah tidur malamnya?

\begin{tabular}{|l|l|l|l|}
\hline $\begin{array}{l}\mathrm{N} \\
\mathrm{O}\end{array}$ & $\begin{array}{l}\text { Tanggap } \\
\text { an }\end{array}$ & $\begin{array}{l}\text { frekuen } \\
\text { si }\end{array}$ & $\begin{array}{l}\text { Persenta } \\
\text { se }\end{array}$ \\
\hline 1 & Ya & 49 & $98 \%$ \\
\hline 2 & Tidak & 1 & $2 \%$ \\
\hline & TOTAL & 50 & $100 \%$ \\
\hline
\end{tabular}

7. Perhitungan data jawaban pertanyaan nomor tujuh

‥ Pertanyaan:

Terkadang beberapa jadwal kuliah dimulai pagi hari sekira pukul 7.30. apakah anda percaya diri untuk bisa bangun pagi? 
Research Fair Unisri 2019

Vol 4, Number 1, Januari 2020

\begin{tabular}{|l|l|l|l|}
\hline $\begin{array}{l}\mathrm{N} \\
\mathrm{O}\end{array}$ & $\begin{array}{l}\text { Tanggap } \\
\text { an }\end{array}$ & $\begin{array}{l}\text { frekuen } \\
\text { si }\end{array}$ & $\begin{array}{l}\text { Persenta } \\
\text { se }\end{array}$ \\
\hline 1 & Ya & 31 & $62 \%$ \\
\hline 2 & Tidak & 19 & $38 \%$ \\
\hline & TOTAL & 50 & $100 \%$ \\
\hline
\end{tabular}

8. Perhitungan data jawaban pertanyaan nomor delapan

Pertanyaan:

Karena kebutuhan bermain game sudah semakin tinggi, apakah anda merasa kesulitan dalam mengikuti perkuliahan?

\begin{tabular}{|l|l|l|l|}
\hline $\begin{array}{l}\mathrm{N} \\
\mathrm{O}\end{array}$ & $\begin{array}{l}\text { Tanggap } \\
\text { an }\end{array}$ & $\begin{array}{l}\text { frekuen } \\
\text { si }\end{array}$ & $\begin{array}{l}\text { Persenta } \\
\text { se }\end{array}$ \\
\hline 1 & Ya & 48 & $96 \%$ \\
\hline 2 & Tidak & 2 & $4 \%$ \\
\hline & TOTAL & 50 & $100 \%$ \\
\hline
\end{tabular}

9. Perhitungan data jawaban pertanyaan nomor Sembilan

Pertanyaan:

Kegiatan bermain game yang sudah lebiih dari lima jam dan mengurangi jam tidur malam tersebut apakah membuat anda mendapatkan nilai yang tidak baik?

\begin{tabular}{|l|l|l|l|}
\hline $\begin{array}{l}\mathrm{N} \\
\mathrm{O}\end{array}$ & $\begin{array}{l}\text { Tanggap } \\
\text { an }\end{array}$ & $\begin{array}{l}\text { frekuen } \\
\text { si }\end{array}$ & $\begin{array}{l}\text { Persenta } \\
\text { se }\end{array}$ \\
\hline 1 & Ya & 50 & $58 \%$ \\
\hline 2 & Tidak & 21 & $42 \%$ \\
\hline & TOTAL & 50 & $100 \%$ \\
\hline
\end{tabular}

10. Perhitungan data jawaban pertanyaan nomor sepuluh

Pertanyaan:
P- ISSN: 2550-0171

E- ISSN: 2580-5819

Pada kecanduan bermain game online, pendaran syaraf ditemukan di titik yang sama dengan pecandu narkoba. Apakah anda mengetahui hal tersebut?

\begin{tabular}{|l|l|l|l|}
\hline $\begin{array}{l}\mathrm{N} \\
\mathrm{O}\end{array}$ & $\begin{array}{l}\text { Tanggap } \\
\text { an }\end{array}$ & $\begin{array}{l}\text { frekuen } \\
\text { si }\end{array}$ & $\begin{array}{l}\text { Persenta } \\
\text { se }\end{array}$ \\
\hline 1 & Ya & 50 & $100 \%$ \\
\hline 2 & Tidak & 0 & $0 \%$ \\
\hline & TOTAL & 50 & $100 \%$ \\
\hline
\end{tabular}

11. Perhitungan data jawaban pertanyaan nomor sebelas

\section{Pertanyaan:}

Kemampuan untuk mengabaikan hampir apapun dalam hal memenuhi kebutuhan biologis seperti makan, minum, buang air kecil dan besar, dan tidur karena tertutup candu dalam bermain game yang kemudian beujung pada kematian adalah hal krusial yang harus diperhatikan.apakah anda tahu fakta tersebut?

\begin{tabular}{|l|l|l|l|}
\hline $\begin{array}{l}\mathrm{N} \\
\mathrm{O}\end{array}$ & $\begin{array}{l}\text { Tanggap } \\
\text { an }\end{array}$ & $\begin{array}{l}\text { frekuen } \\
\text { si }\end{array}$ & $\begin{array}{l}\text { Persenta } \\
\text { se }\end{array}$ \\
\hline 1 & Ya & 11 & $22 \%$ \\
\hline 2 & Tidak & 39 & $78 \%$ \\
\hline & TOTAL & 50 & $100 \%$ \\
\hline
\end{tabular}

Kesebelas pertanyaan tersebut menanyakan sikap, tanggapan, dan informasi mahasiswa sekitar game online dan konsekwensinya terhadap hasil perkuliahan. Maka, jawaban dari 
kesebelas pertanyaan tersebut, bila digabung menjadi satu, pertanyaannya menjadi, bagaimana hasil atau nilai IP anda pada perkuliahan semenjak menjadi pemain game aktif dengan durasi permainan massiv. Dan jawaban dari pertanyaan tersebut adalah seperti tertera dalam table berikut ini.

\begin{tabular}{|l|l|l|l|}
\hline $\begin{array}{l}\mathrm{N} \\
\mathrm{O}\end{array}$ & $\begin{array}{l}\text { Tanggap } \\
\text { an }\end{array}$ & $\begin{array}{l}\text { frekuen } \\
\text { si }\end{array}$ & $\begin{array}{l}\text { Persenta } \\
\text { se }\end{array}$ \\
\hline 1 & Ya & 456 & $82 \%$ \\
\hline 2 & Tidak & 94 & $17 \%$ \\
\hline & TOTAL & 550 & $100 \%$ \\
\hline
\end{tabular}

Angka-angka dalam table diatas diperoleh dengan cara,

1. Frekuensi jawaban YA, merupakan penjumlahan semua jawaban YA pada kesebelas pertanyaan yang diajukan.

2. Frekuensi jawaban TIDAK, merupakan penjumlahan semua jawaban TIDAK pada kesebelas pertanyaan yang diajukan.

3. Persentase diperoleh dengan rumus sebagai berikut,

$\mathrm{X}=$

Keterangan:

$\mathrm{X}$ : Persentase yang dicari

$\mathrm{F}$ : penjumlahan frekuensi jawaban yang diperoleh melalui sebelas pertanyaan yang diajukan

$\mathrm{N}$ : Jumlah seluruh responden dikaliakn sebelas pertanyaan yaitu 550 .

\section{PENUTUP}

\section{A. Kesimpulan}

Berdasarkan hasil analisis data diatas, peneliti dapat menyimpulkan bahwa:
1. Mahasiswa pemain aktif game online PUBG di Prodi Teknologi Informasi FKIP Unisri tahiun ajaran 2018/2019 yang indeks nilainya terpengaruh karena bermain game online ini sebesar $82 \%$. Sehingga yang jumlah mahasiswa yang bermain game dan indeks nilainya terpengaruh adalah berjumlah 50 orang $\mathrm{x}$ $82 \%=45$ mahasiswa.

Sedangkan, Mahasiswa pemain aktif game online PUBG di Prodi Teknologi Informasi FKIP Unisri tahiun ajaran 2018/2019 yang indeks nilainya tidak terpengaruh karena bermain game online ini sebesar $17 \%$. Sehingga yang jumlah mahasiswa yang bermain game dan indeks nilainya terpengaruh adalah berjumlah 50 orang $\times 17 \%=5$ mahasiswa.

Dengan persentase hasil perhitungan diatas. Peneliti dapat menyatakan bahwa jumlah mahasiswa yang indeks nilainya terpengaruh karena bermain game online ini sebesar $82 \%$. Sedangkan, mahasiswa yang indeks nilainya tidak terpengaruh karena bermain game online ini sebesar 17\%.

2. Dengan persentase hasil perhitungan diatas. Peneliti dapat menyatakan bahwa jumlah mahasiswa pemain aktif game online PUBG di Prodi Teknologi Informasi FKIP Unisri tahiun ajaran 2018/2019yang indeks nilainya terpengaruh karena bermain game online ini sebesar $82 \%$. Sedangkan, Mahasiswa pemain aktif game online PUBG di Prodi 
Teknologi Informasi FKIP Unisri tahiun ajaran 2018/2019yang indeks nilainya tidak terpengaruh karena bermain game online ini sebesar $17 \%$.

\section{B. Saran}

Sehubungan denan kesimpulan diatas, bahwa ada sekitar $82 \%$ Mahasiswa pemain aktif game online PUBG di Prodi Teknologi Informasi FKIP Unisri tahiun ajaran 2018/2019. Peneliti memberikan saran, hendaknya orang tua, dosen, serta tokoh-tokoh masyarakat selalu mengingatkan bahwa kecanduan bermain game sama berbahayanya dengan kecanduan narkoba. Karena mampu mematikan rangsangan-rangsangan mendasar seperti makan, minum, tidur, dan buang air kecil dan besar, bahkan jika diabaikan, dapat berimbas pada kematian.

\section{DAFTAR PUSTAKA}

Aditya, Ramadhan. 24 September 2013. Survei: 97\% Remaja Indonesia Mengakses Situs Porno. Okezone News. (online). (http://techno.okezone.com/read/ 2013/09/24/55/870832/survei-97remaja-indonesia-mengaksessitus-porno, diakses tanggal 4 Maret 2016).

Fachruddin, Fuad. Reseach Method In Language Education. 2011. Jakarta: Program Magister PBI FITK UIN Syahid.

Maleong, J. Lexy. 2000. Metodologi Penelitian Kualitatif. Bandung: Remaja Rosda Karya.
Pornografi.

(online)

(http://id.wikipedia.org/wiki/Por

nografi, diakses tanggal 1 Maret 2016)

Purwasih, Joan Hesti, dkk. 2014. Sosiologi. Klaten: Intan Pariwara.

Pusat Bahasa Departemen Pendidikan Nasional. 2007. Kamus Besar

Bahasa Indonesia Edisi III.

Jakarta: PT Balai Pustaka.

S, Margono. 2005. Metodologi Penelitian Pendidikan. Jakarta: Rineka Cipta.

Soebagijo, Azimah. 2008. Pornografi Dilarang tapi Dicari. Depok: Gema Insani.

Sugiyono. 2008. Statistika

Untuk Penelitian. Bandung: CV. Alfabeta.

Teknologi Informasi.

(online). (https://id.wikipedia.org/ wiki/Teknologi_informasi, diakses tanggal 1 Maret 2016).

Tim Redaksi Indonesia Tera. (eds). 2008. Undang-Undang Pornografi dan Penjelasannya. Yogyakarta: Indonesia Tera.

Usman, Husaini dan Purnomo Setiadi. 2000. Metodologi Penelitian Survey. Jakarta: PT Bumi Aksara.

Wirartha, I Made. 2006. Pedoman Penulisan Usulan Penelitian. Yogyakarta: CV. Andi Offset. 